\title{
Peroxidases Produced by New Ligninolytic Bacillus strains Isolated from Marsh and Grassland Decolourized Anthraquinone and Azo Dyes
}

\author{
Ayodeji Falade ${ }^{1,2 *}$, Leonard Mabinya ${ }^{1,2}$, Anthony Okoh ${ }^{1,2}$, Uchechukwu Nwodo ${ }^{1,2}$ \\ ${ }^{1}$ SAMRC Microbial Water Quality Monitoring Centre, University of Fort Hare, Alice, South Africa \\ ${ }^{2}$ Applied and Environmental Microbiology Research Group (AEMREG), Department of Biochemistry \\ and Microbiology, University of Fort Hare, Alice, South Africa
}

Received: 26 April 2018

Accepted: 22 June 2018

\begin{abstract}
The biotechnological relevance of ligninolytic organisms remains topical and may remain so in the foreseeable future. The enzyme battery produced by ligninolytic bacteria, including Bacillus species, has shown immense industrial significance. Consequently, peroxidases produced by newly isolated ligninolytic Bacillus strains from the marsh and grassland in Hogsback forest reserve of the Eastern Cape Province of South Africa were evaluated for decolourization of anthraquinone (Remazol Brilliant Blue R-RBBR) and azo (Congo Red-CR) dyes. Maximum dye decolourization was observed with the peroxidase from Bacillus sp. NWODO-3: CR (69.89 $\pm 2.64 \%)$ and RBBR (72.12 $\pm 0.38 \%)$. Dye decolourization readings for peroxidases from the other Bacillus strains were CR: $55.06 \pm 5.48 \%$, RBBR: $70.45 \pm 0.0 \%$ (Bacillus sp. MABINYA-1), $42.62 \pm 5.55 \%$ and $42.42 \pm 4.82 \%$ against CR for Bacillus sp. MABINYA-2 and Bacillus sp. FALADE-1, respectively. RBBR was less susceptible to the attack by crude peroxidase produced by Bacillus sp. MABINYA-2 and Bacillus sp. FALADE-1 as the dye decolourization activities observed were $4.91 \pm 0.36 \%$ and $1.19 \pm 0.0 \%$, respectively. These results suggest the industrial relevance of peroxidases from the new ligninolytic Bacillus strains in bioremediation.
\end{abstract}

Keywords: bioremediation, dye decolourization, ligninolytic bacteria, lignin-modifying enzymes

\section{Introduction}

Lignin constitutes a major hassle in the conversion of lignocellulosic-carbonoclastic materials to valueadded products. An example of such a valorization process is the utilization of lignocellulose as feedstock for biofuel production. Hence, efficient delignification

*e-mail: ayodeji.falade@yahoo.com of lignocellulosic biomass is imperative. The biological approach to delignification involves the use of microbes or microbial products such as enzymes [1], perhaps due to the mild reaction conditions, increased yield and low energy requirements [2].

The lignin degradation potentials of several fungal species have been studied often and their effectiveness vastly documented [3-6]. However, the emergence of some classes of bacteria as ligninolytic microbes is quite nascent and requires an adept combination of biotechnological tools to unravel the immense potentials 
possessed by the microbes. Some classes of bacteria whose emerging role in lignin degradation has been reported include actinomycetes, $\alpha$-proteobacteria and $\gamma$-proteobactria [7]. Similarly, members of the Bacillus genus have been reported to possess ligninolytic abilities $[8,9]$, and some of these members include Bacillus sp. LD003 [8], Bacillus sp. CS-1 and Bacillus sp. CS-2 [9], and Bacillus ligniniphilus L1 [10]. The lignindegradation activities shown by these microbes have been partly attributed to the production of oxidative enzymes, predominantly peroxidases [11].

Besides the delignification activity of peroxidases, the unique oxidative properties of the enzymes have seen other applications, including dye decolourization and xenobiotic degradation emerge [1]. The high redox potentials of microbial peroxidases and the ability to oxidize recalcitrant phenolic compounds underscore the relevance of these microbes to humanity. Synthetic dyes are recalcitrant to degradation and thus constitute an environmental nuisance upon discharge as industrial effluent. Consequently, the effective removal from the environment through partial or complete degradation remains a challenge.

A physico-chemical treatment approach has been applied for removal of the noxious substances (dye) from the environment. However, these approaches, including adsorption and flocculation, have high limitations and are inefficient [12]. The other downside of these techniques includes high operational cost and the creation of secondary pollution [13]. The biological approach, which includes the use of microorganisms and sub-molecules such as enzymes in the degradation of dye in effluents, has been effective and is saddled with fewer limitations [1]. Hence, the exploration of microbial diversity, besides the already known species, for dye decolourization potentials becomes imperative. Consequently, the ligninolytic bacteria species isolated from marsh and grassland of Hogsback forest reserve were evaluated for peroxidase production and the decolourization of dyes with varied arene substituents.

\section{Material and Methods}

\section{Sampling Site and Sample Collection}

Samples of decaying wood, soil, sediment, moist rock scrapings and water were collected from marsh and grassland in Hogsback forest reserve of the Raymond Mhlaba Municipality, Eastern Cape, South Africa and transported on ice to the Applied and Environmental Microbiology Research Group (AEMREG) Laboratory, University of Fort Hare, Alice, South Africa for analysis.

Hogsback lies on the Amathole Mountains of the Eastern Cape Province of South Africa, with geographical coordinates S32 .598' E26․938'. The pristine forest reserve has waterfalls, and trout fishing is common. The Hogsback forest reserve has been described as the second-largest per unit area in South
Africa comprising indigenous forests, with pockets of Afromontane rain forests covering a large area. Additionally, marsh and grassland are other features of Hogsback.

\section{Isolation of Ligninolytic Bacteria}

Lignin degrading bacteria were isolated using standard techniques [14] with slight modification as previously described by Falade et al. [11].

\section{Lignin Degradation Assay}

The isolates were further evaluated for ligninolytic potential using the modified method of Taylor et al. [15] as described by Falade et al. [11] in a previous study.

\section{Bacteria Identification}

Isolates with promising ligninolytic activity were characterized using 16S rRNA gene sequence analysis as previously described elsewhere [11]. Phylogenetic analysis was conducted by the neighbour-joining method using MEGA 7.0.21 [16].

\section{Peroxidase Activity Screening}

Qualitative peroxidase activity was determined as described by López et al [17]. Briefly, isolates were inoculated in nutrient agar and incubated at $30^{\circ} \mathrm{C}$ for $48 \mathrm{~h}$. Thereafter, $30 \mu \mathrm{L}$ of equal parts of $0.4 \%(\mathrm{v} / \mathrm{v})$ hydrogen peroxide $\left(\mathrm{H}_{2} \mathrm{O}_{2}\right)$ and $1 \%$ pyrogallol in water was added to the colony. Colonies with yellow-brown colour were recorded as positive.

\section{Peroxidase Production and Enzyme Preparation}

Peroxidase was produced in a submerged fermentation system using the method described by Falade et al. [11]. Fermented broth was centrifuged (15000 rpm) for $10 \mathrm{~min}$ at $4^{\circ} \mathrm{C}$ using benchtop cold centrifuge (SIGMA 1-14K). The supernatant was subsequently utilized for peroxidase assay.

\section{Peroxidase Activity Quantitation}

Peroxidase activity was quantified through the measurement of the rate of hydrogen peroxide-dependent oxidation of pyrogallol to purpurogallin in line with standard methods [18, 19], but with slight modification as reported elsewhere [11].

\section{Dye Decolourization Assay}

Lignin-mimicking dyes Remazol Brilliant Blue $\mathrm{R}$ (RBBR) and Congo Red (CR) were assessed for decolourization [8]. About $5 \mu \mathrm{L}$ of an $18 \mathrm{~h}$ culture was aseptically inoculated in dye-agar with the following composition: $\mathrm{K}_{2} \mathrm{HPO}_{4}(4.55 \mathrm{~g} / \mathrm{L}), \mathrm{KH}_{2} \mathrm{PO}_{4}$ 
$(0.53 \mathrm{~g} / \mathrm{L}), \mathrm{MgSO}_{4}(0.5 \mathrm{~g} / \mathrm{L}), \mathrm{NH}_{4} \mathrm{NO}_{3}(5 \mathrm{~g} / \mathrm{L})$, yeast extract (0.1 g/L), glycerol (40 mM), dye (100 mg/L RBBR; $50 \mathrm{mg} / \mathrm{L} \mathrm{CR})$, and agar $(15 \mathrm{~g} / \mathrm{L})$. The cultures were incubated at $30^{\circ} \mathrm{C}$ and examined daily for growth and development of decolourization zones. The total incubation time was $168 \mathrm{~h}$.

Furthermore, the rate of decolourization of the dyes was similarly evaluated in line with the modified method of Kalyani et al. [20]. The reaction mixture $(400 \mu \mathrm{L})$ contained dye $(100 \mathrm{mg} / \mathrm{L})$, potassium phosphate buffer $(0.1 \mathrm{M}, \mathrm{pH} 6)$ and culture supernatant (crude enzyme). The reaction was initiated via the addition of $0.5 \%$ hydrogen peroxide $(30 \% \mathrm{w} / \mathrm{w})$ and subsequently incubated at $25 \pm 2^{\circ} \mathrm{C}$ for $30 \mathrm{~min}$. Absorbance was read at $490 \mathrm{~nm}$ and $590 \mathrm{~nm}$ being the maximum wavelength for CR and RBBR, respectively [21], using SynergyMx 96-well microtitre plate reader (BioTeK Instruments). A reaction mixture without the crude enzyme served as the control. Dye decolourization was measured by monitoring the decrease in absorbance of each dye and expressed as percentage decolourization:

$\frac{\text { Initial Absorbance - Final Absorbance }}{\text { Initial Absorbance }} \times \quad 100 \%$

\section{Data Analysis}

All data, including absorbance readings and halo zones, were subjected to analysis of variance (ANOVA) using GraphPad Prism 7 at a 5\% $(P \leq 0.05)$ confidence interval. Where applicable, results were presented as mean values \pm standard deviation (STD).

\section{Results and Discussion}

\section{Isolation of Ligninolytic Bacteria}

A total of 49 ligninolytic bacteria were isolated from marsh and grassland in Hogsback located in Raymond Mhlaba Municipality, Eastern Cape, South Africa (Table 1). The isolates were presumed to be ligninolytic due to their ability to utilize alkali lignin as the sole carbon source in an enrichment medium. Isolation of bacteria with ligninolytic potential from different samples has previously been reported $[8,9,15$, 22, 23]. Hemati et al. [24] reported the isolation of lignocellulolytic bacteria from composts and soils in Iran. Naz [25] isolated and characterized ligninolytic bacteria from Kuthrel Agro Field in India. Also, Lai et al. [26] reported the isolation of thermophilic ligninolytic bacteria from oil palm empty-fruit bunch compost in Malaysia. However, this is the first report of isolation of ligninolytic bacteria from Hogsback forest reserve in South Africa.

Organisms with ligninolytic potential are promising candidates for delignification of feedstock for bioethanol production [1]. They are as well significant in the valorization of lignocellulose to other value-added products. Besides the imperativeness of ligninolytic organisms in the valorization of lignocellulosic biomass, they also have the potential for the production of ligninolytic enzymes, including peroxidases and laccase $[25,27]$, with significant prospective industrial applications. Furthermore, ligninolytic bacteria have shown prospect in bioremediation. For instance, Hooda et al. [28] employed ligninolytic bacteria for the treatment of pulp and paper mill effluent. The study established that Brevibacillus agri, a lignin-degrading bacteria, was able to reduce the colour and chemical oxygen demand (COD) of the treated wastewater. Similarly, Raj et al. [29] reported the bioremediation and toxicity reduction potential of ligninolytic bacteria. Specifically, treatment of pulp and paper mill effluent by Paenibacillus sp. LD1 , a ligninolytic organism, showed that the COD and BOD (biological oxygen demand) of the treated effluent was reduced by 78 and $83 \%$, respectively, after $144 \mathrm{~h}$, while about an $86 \%$ reduction in phenol content was recorded after the treatment. It is therefore evident that ligninolytic bacteria are promising candidates for the treatment of wastewater effluent discharged from pulp and paper mills as lignin is a major component of the effluent [29].

\section{Lignin Degradation Potential}

Besides the utilization of alkali lignin as the sole carbon source, the ligninolytic potential of the isolates was also assessed using their ability to utilize and degrade some lignin model compounds, including 2-Methoxyphenol (guaiacol) and 3,4-Dimethoxybenzyl alcohol (veratryl alcohol). The use of different lignin model compounds and aromatic monomers such as benzaldehyde, benzoic acid, guaiacol, veratryl alcohol, catechol, syringol, vanillic acid, and vanillin for screening of organisms for ligninolytic potentials has been reported $[8,11,15,30]$. Table 2 showed that 13 isolates $(26.5 \%)$ were able to utilize and degrade both guaiacol and veratryl alcohol. The degree of degradation of the compounds by the isolates was measured by the diameter of the halo zone with isolate HBB1A having the highest zone of degradation for the two compounds (guaiacol: $42.0 \pm 0.0 \mathrm{~mm}$, veratryl alcohol: $41.0 \pm 1.0 \mathrm{~mm}$ ), while HBB29C had the lowest zone of degradation (guaiacol: $9.0 \pm 1.0 \mathrm{~mm}$, veratryl alcohol: $7.0 \pm 1.0 \mathrm{~mm}$ ). The degraded part was revealed as a clear zone around the bacterial colony on plate while the brown colouration of the un-degraded part resulted from the interaction of hydrogen iodide (generated from dissolving potassium iodide and iodine in water) with the two aromatic alcohols in the presence of oxygen after being flooded with Gram's iodine [11] at $168 \mathrm{~h}$ of incubation. The clear zone around the bacterial colony in this study could either be a result of utilization of the compounds or their degradation by extracellular enzymes, including lignin-modifying enzymes. Furthermore, the capability of bacterial strains to utilize 
Table 1. Colonial morphology of isolated bacteria on alkali lignin plate.

\begin{tabular}{|c|c|c|c|c|c|c|}
\hline $\mathrm{S} / \mathrm{N}$ & Isolate ID & Isolation source & Form & Pigmentation & Elevation & Margin \\
\hline 1. & HBB1A & Decaying wood & Circular & Creamy & Raised & Entire \\
\hline 2. & HBB1B & Decaying wood & Circular & Yellowish & Raised & Entire \\
\hline 3. & HBB2A & Decaying wood & Circular & Transparent & Flat & Undulate \\
\hline 4. & HBB2B & Decaying wood & Circular & Milky & Raised & Entire \\
\hline 5. & HBB4A & Soil & Circular & Creamy & Flat & Entire \\
\hline 6. & HBB4B & Soil & Irregular & Creamy & Flat & Undulate \\
\hline 7. & HBB4C & Soil & Irregular & Transparent & Flat & Undulate \\
\hline 8. & HBB5A & Soil & Irregular & Creamy & Flat & Undulate \\
\hline 9. & HBB5B & Soil & Irregular & Creamy & Flat & Undulate \\
\hline 10. & HBB6A & Sediment & Circular & Transparent & Raised & Entire \\
\hline 11. & HBB7A & Sediment & Irregular & Creamy & Flat & Undulate \\
\hline 12. & HBB8A & Sediment & Irregular & Brownish & Flat & Undulate \\
\hline 13. & HBB8B & Sediment & Circular & Transparent & Raised & Entire \\
\hline 14. & HBB9A & Soil scrapping & Circular & Creamy & Raised & Entire \\
\hline 15. & HBB10A & Soil scrapping & Circular & Creamy & Raised & Entire \\
\hline 16. & HBB11A & Soil scrapping & Circular & Creamy & Raised & Entire \\
\hline 17. & HBB11B & Soil scrapping & Circular & Creamy & Flat & Entire \\
\hline 18. & HBB12A & Decaying wood & Circular & Creamy & Raised & Entire \\
\hline 19. & HBB13A & Soil scrapping & Circular & Creamy & Raised & Entire \\
\hline 20. & HBB13B & Soil scrapping & Circular & Yellowish & Raised & Entire \\
\hline 21. & HBB13C & Soil scrapping & Circular & Whitish & Raised & Entire \\
\hline 22. & HBB14A & Decaying wood & Irregular & Creamy & Flat & Undulate \\
\hline 23. & HBB15A & Moist soil & Irregular & Whitish & Flat & Undulate \\
\hline 24. & HBB16A & Decaying wood & Irregular & Milky & Flat & Undulate \\
\hline 25. & HBB18A & Decayed wood & Circular & Yellowish & Raised & Entire \\
\hline 26. & HBB19A & Water & Circular & Creamy & Raised & Entire \\
\hline 27. & HBB20A & Water & Circular & Creamy & Raised & Entire \\
\hline 28. & HBB21A & Sediment & Irregular & Whitish & Flat & Undulate \\
\hline 29. & HBB21B & Sediment & Circular & Yellowish & Raised & Entire \\
\hline 30. & HBB22A & Water & Circular & Yellowish & Raised & Entire \\
\hline 31. & HBB22B & Water & Circular & Creamy & Raised & Entire \\
\hline 32. & HBB23A & Sediment & Circular & Yellowish & Raised & Entire \\
\hline 33. & HBB23B & Sediment & Circular & Creamy & Raised & Entire \\
\hline 34. & HBB24A & Sediment & Circular & Yellowish & Raised & Entire \\
\hline 35. & HBB25A & Rock scrapping & Circular & Creamy & Raised & Entire \\
\hline 36. & HBB26A & Waterfall sediment & Circular & Yellowish & Flat & Entire \\
\hline 37. & HBB27A & Waterfall sediment & Circular & Yellowish & Raised & Entire \\
\hline 38. & НBB27B & Waterfall sediment & Irregular & Creamy & Flat & Undulate \\
\hline 39. & HBB28A & Rock scrapping & Circular & Yellowish & Raised & Entire \\
\hline
\end{tabular}


Table 1. Continued.

\begin{tabular}{|c|c|c|c|c|c|c|}
\hline 40. & HBB29A & Rock scrapping & Irregular & Creamy & Flat & Undulate \\
\hline 41. & HBB29B & Rock scrapping & Circular & Yellowish & Raised & Entire \\
\hline 42. & HBB29C & Rock scrapping & Circular & Creamy & Raised & Entire \\
\hline 43. & HBB30A & Decayed wood & Circular & Yellowish & Raised & Entire \\
\hline 44. & HBB31A & Soil particles & Irregular & Transparent & Flat & Undulate \\
\hline 45. & HBB32A & Sediment & Circular & Creamy & Flat & Entire \\
\hline 46. & HBB32B & Sediment & Irregular & Creamy & Flat & Undulate \\
\hline 47. & HBB34A & Decayed wood & Circular & Creamy & Raised & Entire \\
\hline 48. & HBB35A & Moist decayed wood & Irregular & Transparent & Flat & Undulate \\
\hline 49. & HBB35B & Moist decayed wood & Irregular & Creamy & Flat & Undulate \\
\hline
\end{tabular}

and degrade guaiacol and veratryl alcohol as observed in this study may also be attributed in part to the activity of alcohol dehydrogenase, which is required to oxidize aromatic alcohols. This finding is in agreement with the work of Tian et al. [31], where ligninolytic bacteria belonging to Serratia, Pseudomonas, Stenotrophomonas and Mesorhizobium species were able to mineralize guaiacol, veratryl alcohol and biphenyl. However, our results contradict the findings of Bandounas et al. [8], who reported that certain bacterial strains including Pandoraea norimbergensis LD001, Pseudomonas sp. LD002 and Bacillus sp. LD003 were not able to utilize or degrade the alcoholic forms of the aromatic monomers investigated, including guaiacol and veratryl

Table 2. Ligninolytic potential of bacterial isolates.

\begin{tabular}{|c|c|c|c|}
\hline $\mathrm{S} / \mathrm{N}$ & $\begin{array}{c}\text { Positive } \\
\text { isolates }\end{array}$ & $\begin{array}{c}\text { Diameter of halo } \\
\text { zone for GA }(\mathrm{mm})\end{array}$ & $\begin{array}{c}\text { Diameter of halo } \\
\text { zone for VA }(\mathrm{mm})\end{array}$ \\
\hline 1. & HBB1A & $42.0 \pm 0.0^{\mathrm{a}}$ & $41.0 \pm 1.0^{\mathrm{a}}$ \\
\hline 2. & HBB1B & $40.0 \pm 2.0^{\mathrm{a}}$ & $39.0 \pm 1.0^{\mathrm{a}}$ \\
\hline 3. & HBB4A & $24.0 \pm 0.0^{\mathrm{b}}$ & $23.0 \pm 1.0^{\mathrm{b}}$ \\
\hline 4. & HBB5A & $26.0 \pm 0.0^{\mathrm{c}}$ & $29.0 \pm 1.0^{\mathrm{c}}$ \\
\hline 5. & HBB5B & $20.0 \pm 0.0^{\mathrm{d}}$ & $25.0 \pm 1.0^{\mathrm{d}}$ \\
\hline 6. & HBB7A & $22.0 \pm 2.0^{\mathrm{d}}$ & $32.0^{ \pm} 0.0^{\mathrm{c}}$ \\
\hline 7. & HBB10A & $12.0 \pm 2.0^{\mathrm{e}}$ & $13.0 \pm 1.0^{\mathrm{e}}$ \\
\hline 8. & HBB11B & $18.0 \pm 2.0^{\mathrm{f}}$ & $20.0 \pm 0.0^{\mathrm{f}}$ \\
\hline 9. & HBB22A & $31.0^{ \pm} 1.0^{\mathrm{g}}$ & $21.0 \pm 1.0^{\mathrm{f}}$ \\
\hline 10. & HBB29A & $31.0 \pm 1.0^{\mathrm{g}}$ & $34.0 \pm 0.0^{\mathrm{g}}$ \\
\hline 11. & HBB29B & $30.0 \pm 2.0^{\mathrm{g}}$ & $34.0 \pm 0.0^{\mathrm{g}}$ \\
\hline 12. & HBB29C & $9.0 \pm 1.0^{\mathrm{h}}$ & $7.0 \pm 1.0^{\mathrm{h}}$ \\
\hline 13. & HBB30A & $17.0^{ \pm} 1.0^{\mathrm{i}}$ & $10.0 \pm 0.0^{\mathrm{i}}$ \\
\hline
\end{tabular}

GA: Guaiacol; VA: Veratryl Alcohol. Values represent mean \pm standard deviation, number of replicate, $n=3$. Values with the same superscript letter along the same column are not significantly different $(P>0.05)$. alcohol. Moreover, Ravi et al. [30] reported the ability of a Pseudomonas sp. to utilize ferulate, $p$-coumarate, benzoate and vanillin. However, the organism could not utilize or grow on syringate and guaiacol. Likewise, Burkholderia sp. strain CCA53 did not utilize guaiacol and veratryl alcohol [32]. Nevertheless, it was able to utilize some other lignin model aromatic monomers, including benzaldehyde, benzoic acid, catechol, syringol, vanillin, 4-hydroxybenzaldehyde, 4-hydroxybenzoic acid and 4-hydroxybenzyl alcohol. The seeming discrepancies in the utilization of lignin model compounds by the different bacteria might be due to ecological reasons as strains studied by Bandounas et al. [8] were isolated from soil beneath decomposing wood logs in the Netherlands, the bacteria from the study of Ravi et al. [30] was isolated from Baltic sea sediments, and Akita et al. [32] isolated their ligninolytic bacteria from soil samples collected in Japan. The bacterial isolates used in this study were from different environments in South Africa. In order to clearly understand these discrepancies, the metagenomics analysis of the samples is imperative.

\section{Bacterial Identity}

Four bacterial isolates with promising ligninolytic potential (HBB5A, HBB5B, HBB7A and HBB29A) were identified using $16 \mathrm{~S}$ rRNA gene sequence analysis and the results showed that all the isolates belong to Bacillus genus. The results of the BLAST search of the respective nucleotide sequences in the NCBI database revealed that HBB5A, HBB5B and HBB29A had 99\% similarity to Bacillus lentus strain FJAT-10603 (JN450800), Bacillus sp. strain NC62 (KY454505) and Bacillus sp. strain FJAT-25753 (KR077842), respectively. However, HBB7A was $100 \%$ similar to Bacillus sp. strain HP5F2 (KM187486) and [Brevibacterium] frigoritolerans strain Hb-1 (KC139406), as it also showed 99\% similarity to several strains of Bacillus species. The respective 16S rRNA gene sequences of the identified organisms are available in the NCBI database with the following 


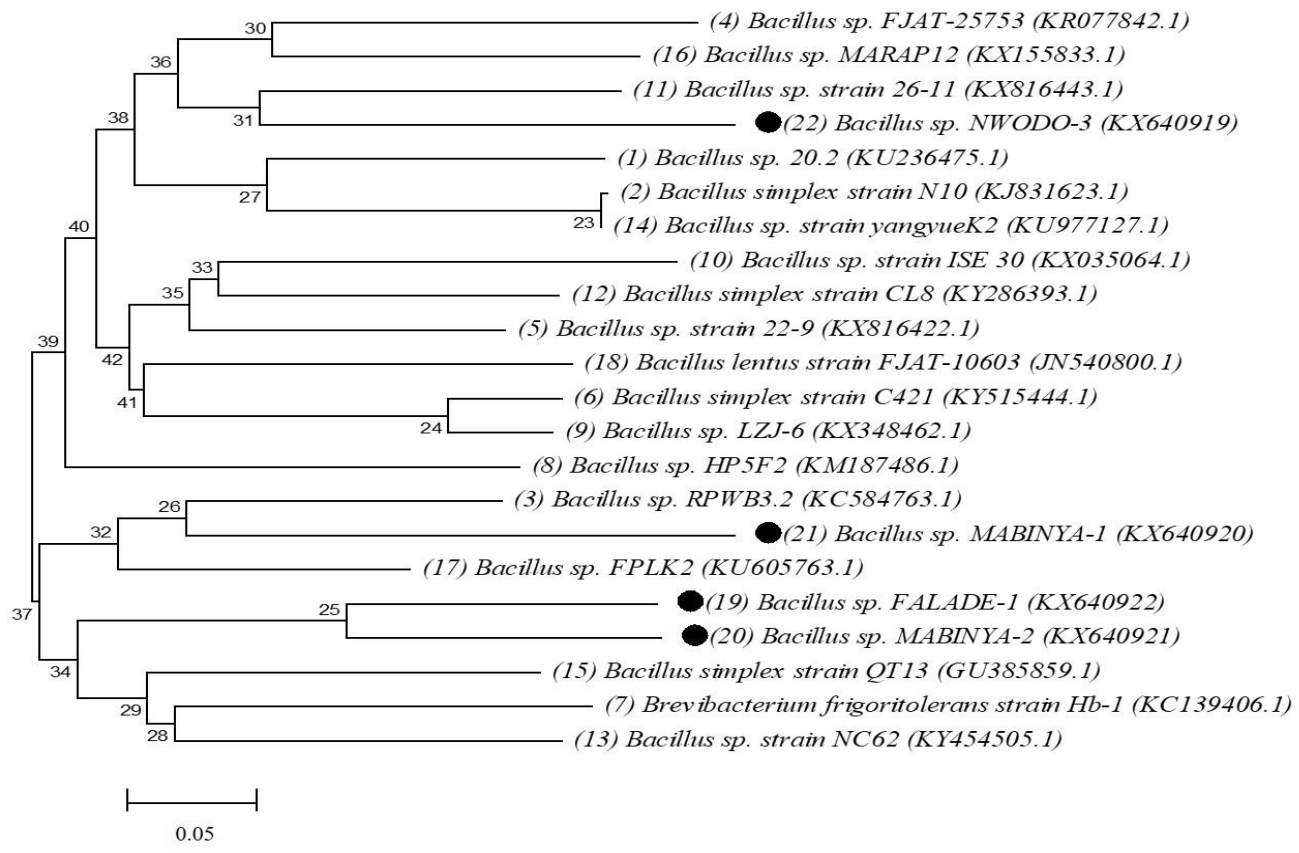

Fig. 1. Phylogenetic tree showing the evolutionary relationships of ligninolytic Bacillus strains in this study and selected Bacillus species in the NCBI database. The ligninolytic bacteria isolated and sequenced in this study are shown in black tips with ID Numbers 19-22. The bootstrap values of 1000 replicates are shown next to the branches while accession numbers are indicated in parentheses.

names and accession numbers: HBB5A: Bacillus sp. strain NWODO-3 (KX640919), HBB5B: Bacillus sp. strain MABINYA-1 (KX640920), HBB7A: Bacillus sp. strain MABINYA-2 (KX640921) and HBB29A: Bacillus sp. strain FALADE-1 (KX640922). The unrooted phylogenetic tree indicating the evolutionary relationships of the Bacillus strains in this study with other Bacillus species available in the NCBI database is shown in Fig. 1. The evolutionary analysis showed that strains FALADE-1 and MABINY-2 are more closely related as they cluster in the same clade.

The identity of these organisms as Bacillus sp. further confirms the emerging role of Bacillus species in lignin degradation. This finding is consistent with previous studies on the ligninolytic activities of Bacillus species where Bandounas et al. [8] reported the ligninolytic potential of Bacillus sp. LD003 isolated from soil in Netherlands. Also, Chang et al. [9] reported the lignin-degrading activity of Bacillus sp. CS-1 and Bacillus sp. CS-2 from forest soils in Japan. This is also corroborated by Zhu et al. [10], who documented the lignin degradation potential of Bacillus ligniniphilus L1 from sea sediment in South China. Furthermore, the results of Naz [25] have also implicated Bacillus species in lignin degradation activity. The emerging ligninolytic activity of Bacillus species confers on this class of bacteria the potential for application in biological delignification, consequently enhancing valorization of lignocellulosic biomass to value-added products of economic importance such as biofuel.

\section{Peroxidase Production by Novel Ligninolytic Bacillus species}

Bacillus species have been described as one of the most significant industrial producers of enzymes, partly owing to their capacity to produce a large amount of extracellular enzymes [33]. To assess the potential of the newly isolated ligninolytic Bacillus species to produce extracellular peroxidases, the qualitative peroxidase

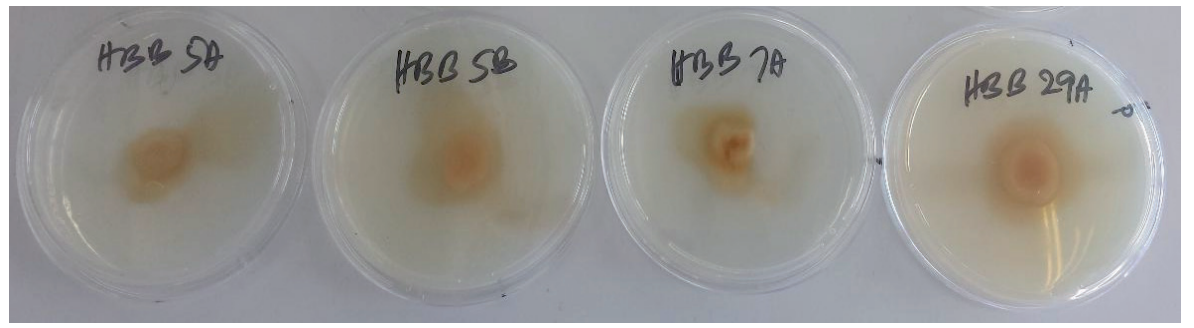

Fig. 2. Qualitative peroxidase activity screening. HBB5A: Bacillus sp. NWODO-3, HBB5B: Bacillus sp. MABINYA-1, HBB7A: Bacillus sp. MABINYA-2, HBB29A: Bacillus sp. FALADE-1. 
Table 3. Peroxidase production by novel ligninolytic Bacillus species.

\begin{tabular}{|c|c|c|}
\hline $\mathrm{S} / \mathrm{N}$ & Organisms & $\begin{array}{c}\text { Peroxidase activity } \\
\left(\mathrm{U} \mathrm{mL}^{-1}\right)\end{array}$ \\
\hline 1. & Bacillus sp. NWODO-3 & 3.03 \\
\hline 2. & Bacillus sp. MABINYA-1 & 1.52 \\
\hline 3. & Bacillus sp. MABINYA-2 & 4.08 \\
\hline 4. & Bacillus sp. FALADE-1 & 6.53 \\
\hline
\end{tabular}

activity of the organisms was determined. The results revealed that all the ligninolytic Bacillus species assessed showed peroxidase activity on plate (Fig. 2) with the presence of yellowish-brown colouration on the bacterial colony after its reaction with $0.4 \%(\mathrm{v} / \mathrm{v})$ hydrogen peroxide $\left(\mathrm{H}_{2} \mathrm{O}_{2}\right)$ and $1 \%$ pyrogallol at $48 \mathrm{~h}$ of incubation on nutrient agar [17]. To further evaluate the peroxidase production potentials of these organisms, the level of extracellular peroxidase produced by the ligninolytic Bacillus species was determined using a quantitative assay as described in the method, and the result is presented in Table 3. Bacillus sp. FALADE-1 exhibited the highest potential for peroxidase production with $6.53 \mathrm{U} \mathrm{mL}^{-1}$ followed by Bacillus sp. MABINYA-2 and Bacillus sp. NWODO-3 with $4.08 \mathrm{U} \mathrm{mL}^{-1}$ and $3.03 \mathrm{U} \mathrm{mL}^{-1}$ of peroxidase, respectively, while Bacillus sp. MABINYA-1 produced $1.52 \mathrm{U} \mathrm{mL}^{-1}$ of peroxidase. However, all the ligninolytic Bacillus species in this study showed promising potential for peroxidase production. The peroxidase yield by these organisms is higher than what was reported by Rao and Kavya [34] and Musengi et al. [35], where Bacillus subtilis and Streptomyces sp. BSII\#1 produced $0.00045 \mathrm{U} \mathrm{mL}^{-1}$ and $1.30 \mathrm{U} \mathrm{mL}^{-1}$ of peroxidase, respectively. This finding is consistent with previous related studies that have reported the potential production of different ligninmodifying enzymes by various ligninolytic bacteria. Min et al. [36] extracted a dye-decolourizing peroxidase from Bacillus subtilis KCTC2023, a ligninolytic bacteria. Moreover, Chantarasiri and Boontanom [27] in their study reported the potential of ligninolytic Lysinibacillus sphaericus JD1103 to produce lignin peroxidase. In one of our previous studies, we also reported the peroxidase production potential of two ligninolytic proteobacteria: Raoultella ornithinolytica OKOH-1 and Ensifer adhaerens NWODO-2 [11]. Similarly, Xu et al. [37] recorded excellent lignin peroxidase and manganese peroxidase activities in Pseudomonas putida NX-1 with kraft lignin degradation activity.

\section{Dye Decolourization}

Decolourization of lignin-like dyes such as Azure B, Methylene Blue, Toluidine Blue O, Malachite Green, Indigo Carmine, RBBR, and CR, etc., has been used to determine the ligninolytic potential of bacteria [8]. To further confirm the ligninolytic potential of the isolates, the 13 positive isolates for the degradation of lignin model compounds (guaiacol and veratryl alcohol) were evaluated for their abilities to decolourize two ligninolytic indicator dyes: RBBR and CR, with different arene substituent attachment positions.

RBBR is a recalcitrant anthraquinone dye with its aromatic substituent attached at the para position of its structural backbone (anthraquinone), while CR is an azo dye having its two azo groups $(-\mathrm{N}=\mathrm{N}-)$ that serve as the chromophore attached at the ortho position [11]. The position of attachment of the various arene rings may probably contribute to the recalcitrance of synthetic dyes to degradation. Consequently, degradation of dyes with ortho, meta and para arene substituents would suffice as a novel mechanism of dye degradation.

The results of the qualitative assessment of the bacterial isolates for dye decolourization as revealed in Table 4 showed 5 isolates $(38.46 \%)$ decolourized RBBR, while 11 isolates $(84.62 \%)$ were positive for decolourization of $\mathrm{CR}$ within $72 \mathrm{~h}$. This finding suggests that CR (azo dye) is more susceptible to decolourization than RBBR, an athraquinone dye. However, only Bacillus sp. NWODO-3, Bacillus sp. MABINYA-1, Bacillus sp. MABINYA-2 and Bacillus sp. FALADE-1 were able to decolourize both RBBR and CR in this study. The dye decolourization observed in this study could be a result of enzymatic oxidation by extracellular enzymes secreted by the bacteria. Moreover, decolourization of $\mathrm{CR}$ and RBBR by the Bacillus species also indicate ligninase activity [24, 38], which further justifies the peroxidase production potential of the studied organisms. Other ligninolytic bacteria species with dye decolourization potential have been reported. In a study by Tian et al. [31], the authors

Table 4. Qualitative assessment of bacteria for dye decolourization

\begin{tabular}{|c|c|c|c|}
\hline S/N & Isolates & RBBR & CR \\
\hline 1. & HBB1A & - & + \\
\hline 2. & HBB1B & - & + \\
\hline 3. & HBB4A & - & + \\
\hline 4. & HBB5A & + & + \\
\hline 5. & HBB5B & + & + \\
\hline 6. & HBB7A & + & + \\
\hline 7. & HBB10A & + & - \\
\hline 8. & HBB11B & - & + \\
\hline 9. & HBB22A & - & + \\
\hline 10. & HBB29A & + & + \\
\hline 11. & HBB29B & - & - \\
\hline 12. & HBB29C & - & + \\
\hline 13. & HBB30A & - & + \\
\hline
\end{tabular}

+: positive; -: negative; RBBR: Remazol Brilliant Blue R; CR: Congo Red. 


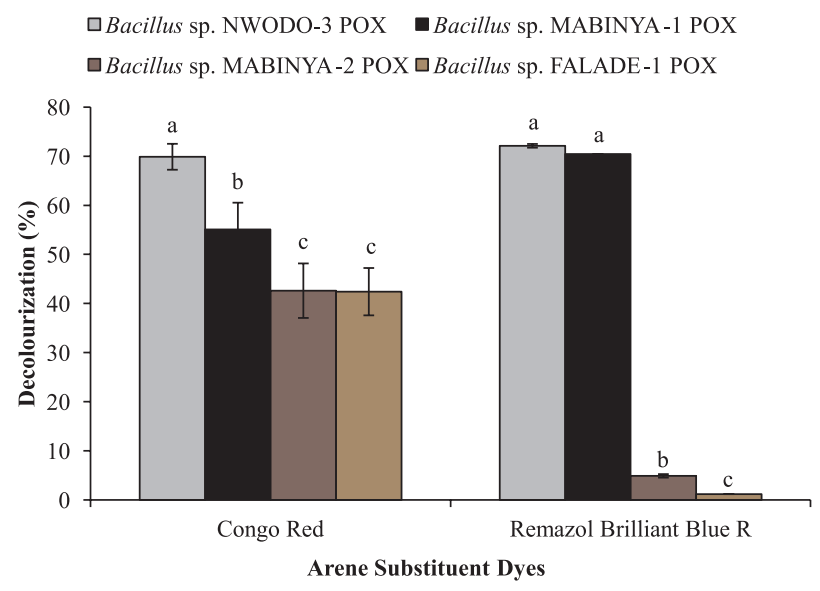

Fig. 3. Decolourization of anthraquinone and azo dyes by peroxidases from new ligninolytic Bacillus strains. Error bars with the same alphabet are not significantly different $(P>0.05)$. POX: Peroxidase.

reported the decolourization of methylene blue and RBBR by ligninolytic Serratia sp. In another study by Chantarasiri and Boontanom [27], CR and RBBR were also decolourized by Lysinibacillus sphaericus JD1103, a ligninolytic bacteria isolated from wetlands in Thailand.

Nevertheless, enzyme-based dye decolourization is of greater interest, partly due to its efficiency, greater specificity and non-dependence on the growth rates of organisms [20, 39]. The involvement of microbial enzymes including peroxidases, laccases and azo reductase in biodegradation of dyes has been suggested [20]. Moreover, crude and purified forms of bacterial peroxidase have been used in dye decolourization $[40,41]$. However, considering the cost of enzyme purification, the use of crude enzyme is being encouraged. Therefore, the potential activity of crude peroxidase produced by the new ligninolytic Bacillus species in dye decolourization was evaluated by incubating the culture supernatant from the organisms with the dyes (CR and RBBR) at $25 \pm 2^{\circ} \mathrm{C}$ for $30 \mathrm{~min}$ in a reaction mixture containing phosphate buffer ( $\mathrm{pH}$ 6) and hydrogen peroxide. The results (Fig. 3) revealed that crude peroxidase from Bacillus sp. NWODO-3 showed the highest decolourization activity for both CR $(69.89 \pm 2.64 \%)$ and RBBR (72.12 $\pm 0.38 \%$ ), followed by peroxidase from Bacillus sp. MABINYA-1 (CR: $55.06 \pm 5.48 \%$, RBBR: $70.45 \pm 0.0 \%$ ). However, there was no significant difference $(P<0.05)$ in the decolourization of $\mathrm{CR}$ by peroxidases from Bacillus sp. MABINYA-2 (42.62 $\pm 5.55 \%)$ and Bacillus sp. FALADE-1 $(42.42 \pm 4.82 \%)$. Although there was a significant difference $(P<0.05)$ in the decolourization of RBBR by peroxidases from Bacillus $\mathrm{sp}$. MABINYA-2 (4.91 $\pm 0.36 \%)$ and Bacillus sp. FALADE-1 $(1.19 \pm 0.0 \%)$, their activities were insignificant. The disparity observed in the decolourization of $\mathrm{CR}$ and RBBR by peroxidases from the Bacillus species may probably be due to the structural variation of the dyes. The result indicates that crude peroxidases from Bacillus sp. NWODO-3 and Bacillus sp. MABINYA-1 showed the best potential activity for arene substituent dye decolourization. This finding is comparable to a previous related study by Kalyani et al. [20], who reported the decolourization of various textile dyes (such as methyl orange, reactive red 2, reactive blue 59 etc.) by peroxidase from Pseudomonas sp. SUK 1 with highest decolourization activity of $72 \%$ on methyl orange. On the other hand, Rekik et al. [42] reported 5\% decolourization of Poly R-478 by peroxidase from Streptomyces griseosporeus SN9 after 48 h. In a similar study by Guo et al. [43], crude manganese peroxidase effectively decolourized an azo dye, Acid Red 18 (AR 18), with more than $80 \%$ decolourization efficiency recorded after 60 min under optimum conditions.

\section{Conclusions}

In conclusion, the four novel ligninolytic Bacillus strains identified in this study have shown promising potential for delignification and production of peroxidases with industrial relevance in bioremediation. The ability of crude peroxidases from Bacillus sp. NWODO-3 and Bacillus sp. MABINYA-1 to decolourize both anthraquinone and azo dyes confers on them the potential for application in textile effluent treatment and synthetic dye transformation. However, further study on detailed characterization of the enzymes and optimization of the dye decolourization process is imperative for industrial applicability.

\section{Acknowledgements}

The authors acknowledge the financial support of the National Research Foundation (NRF) under the South Africa/Tunisia bilateral collaboration (grant No. 95364) and the South African Medical Research Council (SAMRC).

\section{Conflict of Interest}

The authors declare no conflict of interest.

\section{References}

1. FALADE A.O., NWODO U.U., IWERIEBOR B.C., GREEN E., MABINYA L.V., OKOH A.I. Lignin peroxidase functionalities and prospective applications. MicrobiologyOpen, 6, e00394, 2017a.

2. SÁNCHEZ O., SIERRA R., ALMÉCIGA-DÍAZ C.J. Delignification process of agro-industrial wastes an alternative to obtain fermentable carbohydrates for producing fuel. In Alternative fuel, Manzanera, M, Eds., InTech, 111, 2011. 
3. HONG Y., DASHTBAN M., CHEN S., SONG R., QIN W. Lignin in paper mill sludge is degraded by white-rot fungi in submerged fermentation. Microb. Biochem. Technol., 7, 4, 2015.

4. ROUCHES E., ZHOU S., STEYER J.P., CARRERE H. White-rot fungi pretreatment of lignocellulosic biomass for anaerobic digestion: impact of glucose supplementation. Process Biochem., 51, 1784, 2016.

5. MARTINEZ A.T., CAMARERO S., RUIZ-DUENAS F.J., MARTINEZ M.J. Biological lignin degradation. In lignin valorization, Beckham, G. T., Eds., The Royal Society of Chemistry, 199, 2018.

6. WAN C., LI Y. Fungal pretreatment of lignocellulosic biomass. Biotechnol. Adv., 30, 1447, 2012.

7. BUGG T.D.H., AHMAD M., HARDIMAN E.M., SINGH $\mathrm{R}$. The emerging role for bacteria in lignin degradation and bio-product formation. Curr. Opin. Biotechnol., 22, 394, 2011.

8. BANDOUNAS L., WIERCKX N.J., DE WINDE J.H., RUIJSSENAARS, H.J. Isolation and characterization of novel bacterial strains exhibiting ligninolytic potential. BMC Biotechnol., 11, 94, 2011.

9. CHANG Y.C., CHOI D., TAKAMIZAWA K., KIKUCHI S. Isolation of Bacillus sp. strains capable of decomposing alkali lignin and their application in combination with lactic acid bacteria for enhancing cellulase performance. Bioresource Technol., 152, 429, 2014.

10. ZHU D., ZHANG P., XIE C., ZHANG W., SUN J., QIAN W., YANG B. Biodegradation of alkaline lignin by Bacillus ligniniphilus L1. Biotechnol. Biofuels, 10, 44, 2017.

11. FALADE A.O., EYISI O.A.L., MABINYA L.V., NWODO U.U., OKOH A.I. Peroxidase production and ligninolytic potentials of fresh water bacteria Raoultella ornithinolytica and Ensifer adhaerens. Biotechnol. Rep., 16, 12, 2017b.

12. SINGH R.L., SINGH P.K., SINGH R.P. Enzymatic decolorization and degradation of azo dyes-a review. Int. Biodeter. Biodegr., 104, 21, 2015.

13. PARSHETTI G.K., PARSHETTI S., KALYANI D.C., DOONG R., GOVINDWAR S.P. Industrial dye decolorizing lignin peroxidase from Kocuria rosea MTCC 1532. Ann. Microbiol., 62, 217, 2012.

14. SASIKUMAR V., PRIYA V., SHIV S.C., SATHISH S.D. Isolation and preliminary screening of lignin degrading microbes. J. Acad. Indus. Res., 3, 291, 2014.

15. TAYLOR C.R., HARDIMAN E.M., AHMAD M., SAINSBURY P.D., NORRIS P.R., BUGG T.D.H. Isolation of bacterial strains able to metabolize lignin from screening of environmental samples. J. Appl. Microbiol., 113, 521, 2012

16. KUMAR S., STECHER G., TAMURA K. MEGA7: Molecular evolutionary genetics analysis version 7.0 for bigger datasets. Mol. Biol. Evol., 33, 1870, 2016.

17. LÓPEZ M.J., GUISADO G., VARGAS-GARCIA M.C., SUÁREZ-ESTRELLA F., MORENO J. Decolorization of industrial dyes by ligninolytic microorganisms isolated from composting environment. Enzyme Microb. Technol., 40, 42, 2006.

18. CHANCE B., MAEHLY A.C. Assay of catalases and peroxidases. Methods Enzymol., 2, 773, 1955.

19. PARK S. Study of an enzyme activity in extracts of Ginkgo biloba leaves. Bull. Korean Chem. Soc., 27, 1885, 2006.

20. KALYANI D.C., PHUGARE S.S., SHEDBALKAR U.U., JADHAR J.P. Purification and characterization of a bacterial peroxidase from the isolated strain Pseudomonas sp. SUK1 and its application for textile dye decolourization. Ann. Microbiol., 61, 483, 2011.

21. OLLIKKA P., ALHONMÄKI K., LEPPÄNEN V., GLUMOFF T., RAIJOLA T., SUOMINEN, I. Decolorization of azo, triphenyl methane, heterocyclic and polymeric dyes by lignin peroxidase isoenzymes from Phanerocheate chrysosporium. Appl. Environ. Microbiol., 59, 4010, 1993.

22. RAJ A., REDDY M.M.K., CHANDRA R., PUROHIT H.J., KAPLEY A. Biodegradation of kraft-lignin by Bacillus sp. isolated from sludge of pulp and paper mill. Biodegra., 18, 783, 2007.

23. CHANDRA R., RAJ A., POROHIT H.J., KAPLEY A. Characterization and optimization of three potential aerobic bacterial strains for kraft lignin degradation from pulp paper waste. Chemosphere, 67, 839, 2008.

24. HEMATI A., ALIASGHARZAD N., KHAKVAR R. In vitro evaluation of lignocellulolytic activity of thermophilic bacteria isolated from different composts and soils of Iran. Biocatal. Agric. Biotechnol., 2018 [In Press].

25. NAZ S. Study of ligninolytic bacteria isolation and characterization from Kuthrel Agro Field of Bhilai-Durg Region. Int. J. Curr. Microbiol. App. Sci., 5 (12), 141, 2016.

26. LAI C.M.T., CHUN H.B., DANQUAH M.K., SAPTORO A. Isolation of thermophilic lignin degrading bacteria from oil palm empty fruit bunch (EFB) compost. IOP conference series. Mater. Sci. Eng., 206, 012016, 2017.

27. CHANTARASIRI A., BOONTANOM P. Decolorization of synthetic dyes by ligninolytic Lysinibacillus sphaericus JD1103 isolated from Thai wetland ecosystems. AACL Bioflux, 10 (4), 814, 2017.

28. HOODA R., BHARDWAJ N.K., SINGH P. Screening and identification of ligninolytic bacteria for the treatment of pulp and paper mill effluent. Water, Air, Soil Pollut., 226, 305, 2015.

29. RAJ A., KUMAR S., HAG I., SINGH, S.K. Bioremediation and toxicity reduction in pulp and paper mill effluent by newly isolated ligninolytic paenibacillus sp. Ecol. Eng., 71, 355, 2014.

30. RAVI K., GARCIA-HIDALGO J., NOBEL M., GORWAGRAUSLUND M.F., LIDEN G. Biological conversion of aromatic monolignol compounds by a Pseudomonas isolate from sediments of the Baltic sea. AMB Expr., 8, 32, 2018.

31. TIAN J.H., POURCHER A.M., PEU P. Isolation of bacterial strains able to metabolize lignin and ligninrelated compounds. Lett. Appl. Microbiol., 63, 30, 2016.

32. AKITA H., KIMURA Z., YUSOFF M.Z.M., HOSHINO T. Isolation of Pseudomonas sp. strain CCA1 from leaf soil and preliminary characterization its ligninolytic activity. JSM Biotechnol. Bioeng., 3 (4), 1062, 2016.

33. SCHALLMEY M., SINGH A., WARD O.P. Developments in the use of Bacillus species for industrial production. Can. J. Microbiol., 50, 1, 2004.

34. RAO P.R., KAVYA P. Production, isolation and purification of peroxidase using Bacillus subtilis. $20141^{\text {st }}$ International Congress on Environmental, Biotechnology, and Chemistry Engineering. IPCBEE., 64, 21, 2014.

35. MUSENGI A., KHAN N., LE ROES-HILL M., PLETSCHKE B.I., BURTON S.G. Increasing the scale of peroxidase production by Streptomyces sp. strain BSII\#1. J. Appl. Microbiol., 116, 554, 2014.

36. MIN K., GONG G., WOO, H.M., KIM Y., UM Y. A dyedecolorizing peroxidase from Bacillus subtilis exhibiting substrate-dependent optimum temperature for dyes and $\beta$-ether lignin dimer. Sci. Rep., 5, 8245, 2015. 
37. XU Z., QIN L., CAI M., HUA W., JIN M. Biodegradation of kraft lignin by new isolated Klebsiella pneumoniae, Pseudomonas putida, and Ochrobactrum tritici strains. Environ. Sci. Pollut. Res., 2018 [In Press].

38. TING A.S.Y., TAY H., PEH K.L., TAN W.S., TEE C.S. Novel isolation of thermophilic Ureibacillus terrenus from compost of empty fruit bunches (EFB) of oil palm and its enzymatic activities. Biocatal. Agric. Biotechnol., 2, 162, 2013.

39. HUSAIN Q., HUSAIN M., KULSHRESTHA Y. Remediation and treatment of organic-pollutants mediated by peroxidases: a review. Crit Rev Biotechnol., 29, 94, 2009.

40. DAWKAR V.V., JADHAV U.U., TELKE A.A., GOVINDWAR S.P. Peroxidase from Bacillus sp. VUS and its role in the decolourization of textile dyes. Biotechnol. Bioprocess Eng., 14, 361, 2009.
41. GHODAKE G.S., KALME S.D., JADHAV J.P., GOVINDWAR S.P. Purification and partial characterization of lignin peroxidase from Acinetobacter calcoaceticus NCIM 2890 and its application in decolourization of textile dyes. Appl. Biochem. Biotechnol., 152, 6, 2009.

42. REKIK H., NADIA Z.J., BEJAR W., KOURDALI S., BELHOUL M., HMIDI M., BENKIAR A., BADIS A., SALLEM N., BEJAR S., JAOUADI B. Characterization of a purified decolorizing detergent-stable peroxidase from Streptomyces griseosporeus SN9. Int. J. Biol. Macromol., 73, 253, 2015.

43. GUO M., JIA R., YANG X. Decolorization of the azo dye Acid Red 18 by crude manganese peroxidase: effect of system parameters and kinetic study. Biocatal. Biotransform., 32, 276, 2014. 